\title{
Toxins and Antibiotic Resistance of Methicillin-Resistant Staphylococcus aureus Isolated from Clinical Specimens
}

\author{
Keun Sik Baik', Gwang Seo Ki ${ }^{1,2}$, Han Na Choe', Seong Chan Park', Eun Cho Koh', \\ Hyung Rak Kim ${ }^{1,2}$ and Chi Nam Seong * \\ ${ }^{1}$ Department of Biology, College of Life Science and Natural Resources, Sunchon National University, Suncheon 540-742, Korea \\ ${ }^{2}$ Department of Laboratory Medicine, Saint Garlo Medical Center, Suncheon 540-718, Korea
}

Received October 28, 2010 /Accepted November 28, 2010

\begin{abstract}
Seventy five methicillin- resistant Staphylococcus aureus (MRSA) strains and 24 methicillin- susceptible $S$. aureus (MSSA) were isolated from clinical specimens obtained from a hospital in Suncheon, Jeonnam province, Korea, from July to December, 2009. Antibiotic resistance was determined using the disc diffusion method. Genes encoding enterotoxin (SE), toxic shock syndrome toxin-1 (TSST-1), exfoliative toxin (ET) and Panton-Valentine leukocidin (PVL) were detected by multiplex PCR-mediated amplification using specific primers. Sixty $(80 \%)$ MRSA isolates possessed either one or more toxin genes and the most common pattern that coexisted in MRSA was seb, sec, seg, sei and tst (22.7\%) followed by coexistence of sec, seg, sei and tst genes (18.7\%). Gene pvl encoding leukocidin was not found. Significant correlation between the production of sec, seg, sei and tst genes was found. MRSAs were resistant to erythromycin (89\% of the isolates), gentamicin $(70.7 \%)$, ciprofloxacin $(69.3 \%)$, clindamycin $(61.3 \%)$ and tetracycline $(58.7 \%)$, while MSSAs were susceptible to the antibiotics with the exception of erythromycin. Toxin genes $s e b, s e c$ and tst were related to the tetracycline resistance of MRSA.
\end{abstract}

Key words : Methicillin- resistant Staphylococcus aureus (MRSA), antibiotic resistance, enterotoxin, tetracycline resistance

\section{서 론}

Staphylococcus aureus 는 원내감염과 접촉감염의 원인이 되 는 병원성 세균 중 하나이다[1]. 이 세균은 여러 종류의 세포외 단백질성 독소, 즉, 장독소(enterotoxin; SE), 독성 쇼크 증상 독소 1(toxic shock syndrome toxin-1; TSST-1), 피부박탈성 독 소(exfoliative toxin; ET), 백혈구 용해 독소(Panton-Valentine leukocidin; PVL), 용혈 독소(hemolysin) 그리고 응집소 (coagulase)를 분비한다[12]. 특히 장독소는 $S$. aureus가 식품 내에서 증식하는 과정 중에 생성되며 $1 \mu \mathrm{g}$ 이하의 양으로도 식중독을 야기시킬 수 있으며 심한 장 연동의 주요인이 된다 $[3,15]$. 장독소는 항원성에 근거를 둔 혈청학적 분석에 의해 5 종류(SEA, SEB, SEC, SED, SEE)가 확인되었다[3]. 이 장독소 들은 저분자 펩티드로서 아미노산 조성이 매우 유사하다[24]. 최근에는 새로운 형의 장독소(SEG, SEH, SEI, SEJ, SEK, SEL, $\mathrm{SEM}, \mathrm{SEN}, \mathrm{SEO}$ )들이 보고되었으나 식중독과의 연관성은 정 확하지 않다[29]. TSST-1은 발열, 혈압저하, 발적 등을 일으키 는 독소이며, PVL은 피부에 종기나 괴저를 유발한다[15,10]. 이러한 독소 양상은 S. aureus의 유전형과 연관이 있으며, 각 균주별 특성을 나타내므로 이를 분자생물학적 역학 분석에

*Corresponding author

Tel : +82-61-750-3613, Fax : +82-61-750-5469

E-mail : scnu@scnu.ac.kr
사용할 수 있다 $[5,8,27,31,33]$.

Methicillin 내성 Staphylococcus aureus (MRSA)는 methicillin이 쓰이기 시작한 이후로 즉시 나타났으며[14], 이 내성은 $\beta$-lactamase에 의한 것이 아니고 내인성유전자에 기인한다. $\mathrm{MRSA}$ 의 내성 기전은 세균이 선천적으로 염색체 내에 $\operatorname{mec} A$ (methicillin resistant determinant A) 유전자를 획득하여 약제 에 친화성이 적은 세포벽합성단백인 PBP (penicillin binding protein) $2 \mathrm{a}$ 또는 $2^{\prime}$ 에 의하여 생긴다[4,9]. 또한 methicillin의 내성을 증가시키는 보조 유전자인 $\operatorname{fem} A$ (factor essential for methicillin resistance A) 유전자는 mec $A$ 와 협조하여 $\beta$-lactam 항균제에 대한 내성을 나타낸다. MRSA는 $\beta$-lactam계 외에도 아미노글리코시드(aminoglycoside)와 퀴놀론(quinolone)계 그리고 테트라사이클린(tetracycline) 계의 항생제에도 흔히 내성을 나타낸다[2,19]. 이러한 MRSA의 감염은 유럽에서 처 음 발생한 이래 전세계적으로 증가하고 있으며, 원내 감염의 중요한 문제로 대두되어 1960년대 말 국내에서 처음 분리된 이후 점점 증가하여 S. aureus 중 MRSA의 비율은 1995년 이후 $70 \%$ 정도로 일정 비율을 유지하고 있으며 특히 중환자실에서 분리된 균주들에서는 $90 \%$ 에 달하여 세계적으로 가장 높은 수 준의 MRSA 비율을 보인다[2,21,30].

본 연구는 2009년 7월부터 2009년 12월까지 순천 한 병원의 환자 검체로부터 분리된 $\mathrm{MRSA}$ 와 methicillin 감수성 Staphylococcus aureus (MSSA) 균주을 대상으로 장독소를 비롯 
하여, 표피박탈성독소, 독성 쇼크 증상 독소 1 , leukocidin 유전 자들을 분자생물학적 기술인 PCR 기술을 이용하여 검색하였 다. 또한 독소 유전자 분포를 통해 이들 균주들 간의 분자생물 학적 연관성을 파악하고 독소 유전자와 항생제에 대한 내성과 의 관계를 조사하였다.

\section{재료 및 방법}

\section{Methicillin 내성 Staphylococcus aureus 분리}

2009년 7월부터 12월까지 전남 순천 소재 1 개 병원의 내원 및 입 원환자로부터 채취한 4 가지 검체(혈액, 객담, 농, 소변)로 부터 세균을 분리하였다(Table 1). 세균의 분리는 혈액한천 (6\% 혈액 함유) 배지를 이용하여 $37^{\circ} \mathrm{C}$ 에서 $16-18$ 시간 배양하 여 사용하였다. 분리된 세균 중 coagulase 및 catalase시험[32] 에 양성을 나타내는 균주들을 선별하였다. 선별된 균주들을 Vitek 32 GPI kit (BioMerieux, France)를 이용하여 동정하였 다. 대조균주로는 Staphylococcus aureus ATCC 29213을 사용하 였다. 이 때 동일 환자로부터 반복 분리된 균주는 제외하였다. Methicillin 내성 균주(MRSA)의 판정은 디스크 확산법과 Vitek 2 kit (BioMerieux, France)를 이용한 최소억제 농도 (MIC) 판정을 이용하여 실시하였다. 디스크 확산법에서의 판 정 기준은 CLSI [7]를 따랐으며, oxacillin $(1 \mu \mathrm{g})$ 에 의한 억제대 직경이 $10 \mathrm{~mm}$ 이하이면 내성, $13 \mathrm{~mm}$ 이상이면 감수성인 균 주(MSSA)로 판정하였다. Oxacillin에 대한 MIC 판정기준은 $4 \mathrm{\mu g} / \mathrm{ml}$ 이상을 사용하였다. MRSA로 판명된 균주 중 $m e c A$ 가 검출되지 않은 2 개 균주를 제외한 75 개 균주를 MRSA로 최종 확인하였다. 순수 분리된 세균의 계대 배양은 tryptic soy agar (TSA, Becton Dickinson) 배지를 이용하였다.

\section{$\mathrm{DNA}$ 추출, $\operatorname{mec} A$ 및 독소 유전자 분석}

TSA 배지에 자란 세균 집락으로부터 Choe 등의 방법[6]을 이용하여 DNA를 추출하였으며 실험에 사용할 때까지 $-20^{\circ} \mathrm{C}$ 에 냉동 보관하였다.

mecA 및 독소 유전자의 검사는 기존에 알려진 primer (Table 2)을 이용하여 multiplex PCR 조건으로 증폭하였다 [25]. PCR 반응은 PCR thermal cycler TP 600 (TaKaRa, Japan) 를 이용하였으며, PCR 산물은 $2 \%$ agarose gel에 전기영동한 후 확인하였다.

증폭된 산물이 기존에 알려진 독소 유전자와 동일한 염기서
열인지 확인하기 위해 염기서열을 분석하였으며 결정된 독소 유전자 염기서열의 유사도는 Genbank (NCBI)에 등록된 기존 의 독소 유전자의 염기서열과 비교하였다.

\section{항생제 감수성 검사}

분리균의 항생제 감수성 조사는 디스크 확산법을 사용하여 측정하였다. McFarland 0.5관에 맞춘 세균현탁액을 Mueller Hinton II agar (MHA; Becton Dickinson) 배지에 접종한 후 각각의 항생제가 함유된 디스크를 올려놓고 $37^{\circ} \mathrm{C}$ 에서 $16-18$ 시간 배양한 후 억제대의 직경을 측정하였다. 감수성, 중간내 성, 저항성 기준은 CLSI [7] 기준으로 하였으며 매 시험마다 양성 대조 균주로 Staphylococcus aureus ATCC 25923을 사용하 였다.

\section{결 과}

$m e c A$ 및 독소 유전자 분석

독소 유전자와 항생제 내성을 분석하기 위해 사용된 Staphylococcus aureus는 혈액, 객담, 소변과 농에서 분리한 99 개 균주를 사용하였다. Oxacillin에 대한 내성과 $\operatorname{mec} A$ 유전자 의 보유여부를 이용하여 MRSA와 MSSA균주를 확인하였다. MRSA는 75개 균주(혈액과 객담, 각각 20균주; 소변, 19균주; 농, 16균주)를 그리고 MSSA는 24개 균주(혈액, 8균주; 객담, 4 균주; 소변, 10 균주; 농, 2균주)를 사용하였다(Table 1).

$\operatorname{mec} A$ 및 독소유전자에 특이적인 primer를 사용하여 multiplex PCR 실시한 결과 Fig. 1 과 같은 DNA 절편을 확인할 수 있었다. 그리고 증폭된 산물의 염기서열은 기존에 알려진 독 소 유전자 염기서열과 99.4-100\% 일치하였다.

$\mathrm{MRSA}$ 와 MSSA의 독소 유전자 검출 결과는 Table 3에 나타 나 있다. 일반적으로 MRSA 균주들이 MSSA 균주들에 비해 높은 비율로 독소 유전자를 보유하고 있었다.

장독소 중 식중독을 유발한다고 알려진 5 개의 독소 유전자 중 $s e c$ 는 MRSA 39 개 균주 $(52 \%)$ 가 보유하고 있었으며, $s e b$ 와 $s e d$ 는 각각 17 개(22.7\%)와 1 개 균주에서 확인되었으나 sea와 $s e e$ 유전자는 검출되지 않았다. 그러나 MSSA에서는 5 개 균주 $(20.8 \%)$ 가 sea 유전자를 보유하고 있었다. 최근에 알려진 장독 소 $s e$ 와 $s e i$ 유전자는 MRSA에서는 각각 43 개 $(57.3 \%)$ 와 41 개 균주 $(54.7 \%)$, 그리고 MSSA에서는 각각 5 개 균주(20.8\%)가 확 인되었다.

Table 1. Sources of Staphylococcus aureus clinical isolates

\begin{tabular}{|c|c|c|c|c|c|c|c|c|c|c|}
\hline \multirow{2}{*}{$\begin{array}{l}\text { Hospital ward } \\
\text { /specimens }\end{array}$} & \multicolumn{5}{|c|}{ MRSA } & \multicolumn{5}{|c|}{ MSSA } \\
\hline & $\begin{array}{l}\text { Blood } \\
(\mathrm{n}=20)\end{array}$ & $\begin{array}{c}\text { Sputum } \\
(\mathrm{n}=20)\end{array}$ & $\begin{array}{l}\text { Urine } \\
(\mathrm{n}=19)\end{array}$ & $\begin{array}{c}\text { Pus } \\
(\mathrm{n}=16)\end{array}$ & $\begin{array}{l}\text { Total } \\
(\mathrm{n}=75)\end{array}$ & $\begin{array}{l}\text { Blood } \\
(\mathrm{n}=8)\end{array}$ & $\begin{array}{c}\text { Sputum } \\
(\mathrm{n}=4)\end{array}$ & $\begin{array}{l}\text { Urine } \\
(\mathrm{n}=10)\end{array}$ & $\begin{array}{l}\text { Pus } \\
(\mathrm{n}=2)\end{array}$ & $\begin{array}{c}\text { Total } \\
(\mathrm{n}=24)\end{array}$ \\
\hline Outpatient & 3 & 2 & 13 & 3 & 21 & 7 & & 10 & 2 & 19 \\
\hline General ward & 10 & 11 & 6 & 9 & 36 & 1 & 4 & & & 5 \\
\hline Intensive care unit & 7 & 7 & & 4 & 18 & & & & & \\
\hline
\end{tabular}


Table 2. Nucleotide sequences and anticipated sizes of PCR product for the Staphylococcus aureus gene-specific oligonucleotide primers used in this study

\begin{tabular}{|c|c|c|c|c|c|c|}
\hline Target gene & Primer* & Nucleotide sequence $\left(5^{\prime} \rightarrow 3^{\prime}\right)$ & $\begin{array}{c}\text { GenBank } \\
\text { accession no. }\end{array}$ & $\begin{array}{l}\text { Product } \\
\text { length }(\mathrm{bp})\end{array}$ & $\begin{array}{l}\text { Multiplex } \\
\text { PCR set }\end{array}$ & Reference \\
\hline $\begin{array}{l}\text { Methicillin resistant } \\
\text { determinant } \mathrm{A}\end{array}$ & $\begin{array}{l}\text { mecA-F } \\
\text { mecA-R }\end{array}$ & $\begin{array}{l}\text { TCCAGATTACAACTTCACCAGG } \\
\text { CCACTTCATATCTTGTAACG }\end{array}$ & Y00688 & 162 & A & 28 \\
\hline $\begin{array}{c}\text { Toxic shock } \\
\text { syndrome toxin-1 }\end{array}$ & $\begin{array}{l}t s t-\mathrm{F} \\
t s t-\mathrm{R}\end{array}$ & $\begin{array}{l}\text { GCTTGCGACAACTGCTACAG } \\
\text { TGGATCCGTCATTCATTGTTAT }\end{array}$ & J02615 & 559 & $\mathrm{C}$ & 26 \\
\hline $\begin{array}{c}\text { Panton-Valentine } \\
\text { leukocidin }\end{array}$ & $\begin{array}{l}p v l-\mathrm{F} \\
p v l-\mathrm{R}\end{array}$ & $\begin{array}{l}\text { ATCATTAGGTAAAATGTCTGGACATGATCC } \\
\text { GCATCAASTGTATTGGATAGCAAAAGC }\end{array}$ & X72700 & 433 & $\mathrm{C}$ & 22 \\
\hline \multirow{9}{*}{$\begin{array}{l}\text { Staphylococcal } \\
\text { enterotoxins }\end{array}$} & $\begin{array}{l}\text { sea- } \mathrm{F} \\
\text { sea- } \mathrm{R}\end{array}$ & $\begin{array}{l}\text { GCAGGGAACAGCTTTAGGC } \\
\text { GTTCTGTAGAAGTATGAAACACG }\end{array}$ & M18970 & 521 & A & 26 \\
\hline & $\begin{array}{l}s e b F \\
s e b \cdot R\end{array}$ & $\begin{array}{l}\text { ACATGTAATTTTGATATTCGCACTG } \\
\text { TGCAGGCATCATGTCATACCA }\end{array}$ & M11118 & 667 & B & 23 \\
\hline & $\begin{array}{l}s e c-F \\
\text { sec-R }\end{array}$ & $\begin{array}{l}\text { CTTGTATGTATGGAGGAATAACAA } \\
\text { TGCAGGCATCATATCATACCA }\end{array}$ & X05815 & 284 & A & 26 \\
\hline & $\begin{array}{l}\operatorname{sed} F \\
\operatorname{sed} \mathrm{R}\end{array}$ & $\begin{array}{l}\text { GTGGTGAAATAGATAGGACTGC } \\
\text { ATATGAAGGTGCTCTGTGG }\end{array}$ & M28521 & 385 & A & 26 \\
\hline & $\begin{array}{l}\sec F \\
\sec \mathrm{R}\end{array}$ & $\begin{array}{l}\text { TACCAATTAACTTGTGGATAGAC } \\
\text { СTCTTTGCACCTTACCGC }\end{array}$ & M21319 & 171 & B & 26 \\
\hline & $\begin{array}{l}s e g-F \\
s e g-R\end{array}$ & $\begin{array}{l}\text { CGTCTCCACCTGTTGAAGG } \\
\text { CCAAGTGATTGTCTATTGTCG }\end{array}$ & AF064773 & 328 & B & 26 \\
\hline & $\begin{array}{l}\text { seh } \mathrm{F} \\
\operatorname{seh} \mathrm{R}\end{array}$ & $\begin{array}{l}\text { CAACTGCTGATTTAGCTCAG } \\
\text { GTCGAATGAGTAATCTCTAGG }\end{array}$ & U11702 & 360 & $\mathrm{C}$ & 26 \\
\hline & $\begin{array}{l}\text { sei- } \mathrm{F} \\
\text { sei- } \mathrm{R}\end{array}$ & $\begin{array}{l}\text { CAACTCGAATTTTCAACAGGTACC } \\
\text { CAGGCAGTCCATCTCCTG }\end{array}$ & AF064774 & 466 & B & 26 \\
\hline & $\begin{array}{l}s e j-\mathrm{F} \\
s e j-\mathrm{R}\end{array}$ & $\begin{array}{l}\text { CATCAGAACTGTTGTTCCGCTAG } \\
\text { CTGAATTTTACCATCAAAGGTAC }\end{array}$ & AF053140 & 142 & $\mathrm{C}$ & 26 \\
\hline \multirow{2}{*}{ Exfoliative toxins } & $\begin{array}{l}\text { eta } \mathrm{F} \\
\text { eta- } \mathrm{R}\end{array}$ & $\begin{array}{l}\text { GCAGGTGTTGATTTAGCATT } \\
\text { AGATGTCCCTATTTTTGCTG }\end{array}$ & M17347 & 93 & A & 20 \\
\hline & $\begin{array}{l}e t b \mathrm{~F} \\
e t b \mathrm{R}\end{array}$ & $\begin{array}{l}\text { ACAAGCAAAAGAATACAGCG } \\
\text { GTTTTTGGCTGCTTCTCTTG }\end{array}$ & M17348 & 226 & $\mathrm{C}$ & 13 \\
\hline
\end{tabular}

*Abbrivation: $\mathrm{F}$, forward; $\mathrm{R}$, reverse

Table 3. mecA and toxin genes detected in Staphylococcus aureus clinical isolates

\begin{tabular}{|c|c|c|c|c|c|c|c|c|c|c|c|}
\hline \multirow[b]{2}{*}{ Toxin gene } & \multirow[b]{2}{*}{ Primer* } & \multicolumn{5}{|c|}{ MRSA } & \multicolumn{5}{|c|}{ MSSA } \\
\hline & & $\begin{array}{l}\text { Blood } \\
(n=20)\end{array}$ & $\begin{array}{c}\text { Sputum } \\
(n=20)\end{array}$ & $\begin{array}{l}\text { Urine } \\
(\mathrm{n}=19)\end{array}$ & $\begin{array}{c}\text { Pus } \\
(n=16)\end{array}$ & $\begin{array}{c}\text { Total } \\
(n=75)\end{array}$ & $\begin{array}{l}\text { Blood } \\
(\mathrm{n}=8)\end{array}$ & $\begin{array}{l}\text { Sputum } \\
(\mathrm{n}=4)\end{array}$ & $\begin{array}{l}\text { Urine } \\
(\mathrm{n}=10)\end{array}$ & $\begin{array}{c}\text { Pus } \\
(n=2)\end{array}$ & $\begin{array}{l}\text { Total } \\
(\mathrm{n}=24)\end{array}$ \\
\hline $\begin{array}{c}\text { Methicillin } \\
\text { resistant } \\
\text { determinant A }\end{array}$ & $\operatorname{mec} A$ & 20 & 20 & 19 & 16 & 75 & & & & & \\
\hline $\begin{array}{c}\text { Toxic shock } \\
\text { syndrome toxin- } 1\end{array}$ & tst & 4 & 17 & 4 & 10 & 35 & 2 & 2 & 1 & & 5 \\
\hline $\begin{array}{c}\text { Panton-Valentine } \\
\text { leukocidin }\end{array}$ & $p v l$ & & & & & & 1 & & 2 & & 3 \\
\hline \multirow{8}{*}{$\begin{array}{c}\text { Staphylococcal } \\
\text { enterotoxin }\end{array}$} & sea & & & & & & 2 & 2 & 2 & & 5 \\
\hline & $s e b$ & 3 & 14 & & & 17 & & & & & \\
\hline & $\mathrm{sec}$ & 10 & 16 & 3 & 10 & 39 & & & & & \\
\hline & sed & & & 1 & & 1 & & & & & \\
\hline & seg & 9 & 17 & 6 & 11 & 43 & 3 & 2 & & & 5 \\
\hline & seh & & & 1 & 1 & 2 & & 1 & 4 & & 5 \\
\hline & sei & 7 & 17 & 6 & 11 & 41 & 3 & 2 & & & 5 \\
\hline & sej & 1 & & & & 1 & & & 1 & & 1 \\
\hline Exfoliative toxin & $e t b$ & & & 1 & & 1 & & & & & \\
\hline
\end{tabular}

${ }^{*}$ Genes see and eta are not detected from all the isolates. 


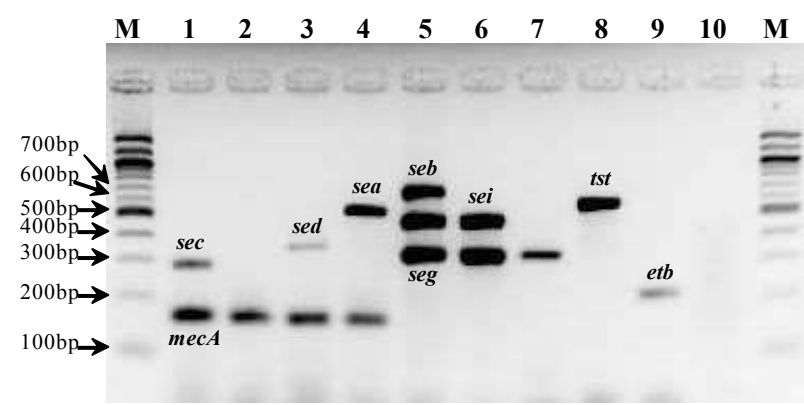

Fig. 1. Agarose gel electrophoresis of the multiplex PCR amplification products from 9 Staphylococcus aureus strains. Lanes $\mathrm{M}, 1 \mathrm{~kb}$ plus DNA ladder; lanes 1-4, primer set A; lanes 5-7, primer set B; lanes 8-9, primer set C. Lane 1, strain S5 (mecA and sec); lane 2, strain U8 (mecA); lane 3, strain U6 (mecA and sed); lane 4, strain B15 (mecA and sea); lane 5, strain S13 (seb, sei and seg); lane 6, strain U10 (sei and seg); lane 7, strain B6 (seg); lane 8, strain S1 (tst); lane 9, strain U5 (etb); lane 10, negative control (distilled water).

피부 박탈성독소b 유전자(etb)는 MRSA 중 1 개 균주가 보 유하고 있었다. 독성 쇼크 증상 독소 1 유전자 $(t s t)$ 를 보유한 균주의 비율은 MRSA는 35개(46.7\%) 그리고 MSSA는 5개 균주 $(20.8 \%)$ 였다. Leukocidin 독소 유전자인 pvl은 MRSA에 서는 검출되지 않은 반면 MSSA 3개 균주(12.5\%)가 보유하 고 있었다. 한편 객담과 농으로부터 분리된 MRSA 균주가 혈액과 소변으로부터 분리된 MRSA에 비해 독소유전자 보 유 빈도가 높음을 알 수 있었다. 특히 sec, seg, seh와 tst 유전 자는 객담과 농으로부터 분리된 $\mathrm{MRSA}$ 의 보유율이 $62.5-85 \%$ 로 혈액과 소변으로부터 분리된 MRSA의 보유율 $15.8-50 \%$ 에 비해 월등히 높았다.

$\mathrm{MRSA}$ 중 44 개 균주가 2개 이상의 독소 유전자를 보유하고 있었다(Table 4). 특히 17 개 균주(객담 분리 균주, 14 ; 혈액 분리
균주, 3)는 $s e b, s e c, s e g, s e i$ 와 $t s t$ 를 동시에 보유하고 있었으며 14 개 균주(객담 분리 균주, 2 ; 소변 분리 균주, 3 ; 농 분리 균주, 8 ; 혈액 분리 균주, 1)는 $s e c, s e g$ sei와 tst를 동시에 보유하고 있었다.

MSSA 균주에서도 여러 개의 독소 유전자를 동시에 보유한 균주가 발견되었다. 특히 4 개 균주가 sea, sei, seg와 tst를 동시 에, 1 개 균주가 sea, seh, pvis와 tst를 동시에 보유하고 있었다(자 료 생략).

MRSA균주들의 각 독소유전자 간의 동시보유율은 Table 5 와 같다. $s e c, s e g s e$ 와 $t s t$ 유전자들 사이의 동시보유율은 $79.1(\mathrm{seg}$ 보유균주가 $t s t$ 를 동시에 보유한 비율)- $100.0 \%$ ( $s e i$ 보 유균주가 $s e g$ 를 동시에 보유한 비율)에 달했다. 그러나 $s e b$ 를 보유한 균주들은 모두 $s e c, s e g, s e$ 와 $t s t$ 유전자들을 보유하지만 그 반대의 경우는 $32.6-40.0 \%$ 에 그쳤다.

\section{항생제 감수성}

MRSA와 MSSA의 항생제에 대한 내성균주 수는 Table 6에 나타나 있다. Quinolone계열의 ciprofloxacin에 대해서는 $69.3 \%$ 의 균주가 내성을 보였으며, amikacin, gentamicin 등 aminoglycoside 계통의 항생제에 대한 내성 균주 비율은 각각 $29.3 \%$ 와 $70.7 \%$ 로 나타났다. 또한 erythromycin, clindamycin 과 tetracycline에 대해서도 각각 $89.3 \%, 61.3 \%$ 그리고 $58.7 \%$ 의 균주가 내성을 나타냈다. 반면, linezolid, nitrofloxacin, teicoplanin과 vancomycin에 대한 내성은 거의 없었다. MSSA의 경우 erythromycin에 대한 내성 균주가 $41.6 \%$ 를 차지한 것 외에 대부분의 항생제에 대한 내성은 낮았다.

MRSA 균주들의 독소유전자 보유와 항생제에 대한 내성율 은 Table 7과 같다. seb 유전자 보유 균주들은 ciprofloxacin, gentamicin과 tetracycline에 대한 내성율이 $90 \%$ 이상이었으 며, sec 유전자 보유 균주들은 tetracycline 에 대한 내성율이

Table 4. Combination of toxin genes detected in methicillin-resistant Staphylococcus aureus clinical isolates

\begin{tabular}{|c|c|c|c|c|c|}
\hline Toxin genes & Blood $(n=20)$ & Sputum $(n=20)$ & Urine $(n=19)$ & Pus $(n=16)$ & Total $(n=75)$ \\
\hline seb, sec, seg, sei, tst & 3 & 14 & & & $17(22.7)$ \\
\hline sec, seg, sei, tst & 1 & 2 & 3 & 8 & $14(18.7)$ \\
\hline sec, seg, sei & 1 & & & 1 & $2(2.7)$ \\
\hline seg, sei, tst & & 1 & & 2 & $3(4.0)$ \\
\hline seg, sei & 2 & & 3 & & $5(6.7)$ \\
\hline sec, seg & 2 & & & & $2(2.7)$ \\
\hline sec, seh & & & & 1 & $1(1.3)$ \\
\hline$e t b$ & & & 1 & & $1(1.3)$ \\
\hline $\mathrm{sec}$ & 3 & & & & $3(4.0)$ \\
\hline sed & & & 1 & & $1(1.3)$ \\
\hline seh & & & 1 & & $1(1.3)$ \\
\hline sej & 1 & & & & $1(1.3)$ \\
\hline tst & & & 1 & & $1(1.3)$ \\
\hline None & 7 & 3 & 9 & 4 & $23(30.7)$ \\
\hline
\end{tabular}

*The numerals in the parentheses are percentage. 
Table 5. Coexistance of toxin genes in methicillin-resistant Staphylococcus aureus clinical isolates

\begin{tabular}{cccccc}
\hline Toxin genes & tst & seb & sec & seg & sei \\
\hline tst & - & $14 / 14(1.000)^{\mathrm{a}}$ & $31 / 39(0.795)$ & $34 / 43(0.791)$ & $34 / 41(0.829)$ \\
seb & $14 / 35(0.400)^{\mathrm{b}}$ & - & $14 / 39(0.359)$ & $14 / 43(0.326)$ & $14 / 41(0.342)$ \\
sec & $31 / 35(0.886)$ & $14 / 14(1.000)$ & - & $35 / 43(0.814)$ & $33 / 41(0.805)$ \\
seg & $34 / 35(0.971)$ & $14 / 14(1.000)$ & $35 / 39(0.897)$ & - & $41 / 41(1.000)$ \\
sei & $34 / 35(0.971)$ & $14 / 14(1.000)$ & $33 / 39(0.846)$ & $41 / 43(0.953)$ & - \\
\hline
\end{tabular}

${ }^{a}$ The rate of existence of a gene of row $(t s t)$ in the strains harboring a gene of column (seb).

${ }^{b}$ The rate of existence of a gene of column $(s e b)$ in the strains harboring a gene of row $(t s t)$.

Table 6. Antibiotic resistance of Staphylococcus aureus clinical isolates

\begin{tabular}{|c|c|c|c|c|c|c|c|c|c|c|}
\hline \multirow[b]{2}{*}{ Antibiotics } & \multicolumn{5}{|c|}{ MRSA } & \multicolumn{5}{|c|}{ MSSA } \\
\hline & $\begin{array}{l}\text { Blood } \\
(\mathrm{n}=20)\end{array}$ & $\begin{array}{c}\text { Sputum } \\
(\mathrm{n}=20)\end{array}$ & $\begin{array}{l}\text { Urine } \\
(\mathrm{n}=19)\end{array}$ & $\begin{array}{c}\text { Pus } \\
(\mathrm{n}=16)\end{array}$ & $\begin{array}{c}\text { Total } \\
(\mathrm{n}=75)\end{array}$ & $\begin{array}{l}\text { Blood } \\
(\mathrm{n}=8)\end{array}$ & $\begin{array}{c}\text { Sputum } \\
(\mathrm{n}=4)\end{array}$ & $\begin{array}{l}\text { Urine } \\
(\mathrm{n}=10)\end{array}$ & $\begin{array}{l}\text { Pus } \\
(n=2)\end{array}$ & $\begin{array}{l}\text { Total } \\
(\mathrm{n}=24)\end{array}$ \\
\hline Amikacin & 14 & 6 & 2 & & 22 & & & & & \\
\hline Ciprofloxacin & 11 & 19 & 11 & 11 & 52 & & & 2 & & 2 \\
\hline Clindamycin & 14 & 16 & 5 & 11 & 46 & & & & & \\
\hline Erythromycin & 13 & 20 & 18 & 16 & 67 & 4 & 2 & 4 & & 10 \\
\hline Gentamicin & 14 & 17 & 12 & 10 & 53 & 2 & & 3 & & 5 \\
\hline Linezolid & & & & & & & & 1 & & 1 \\
\hline Nitrofurantoin & 1 & & & & 1 & & & & & \\
\hline Rifampin & 4 & 7 & 1 & 2 & 14 & & & & & \\
\hline Tetracycline & 10 & 17 & 7 & 10 & 44 & 2 & 1 & 1 & & 4 \\
\hline $\begin{array}{l}\text { Trimethoprim/ } \\
\text { Sulfamethoxazole }\end{array}$ & 2 & 2 & 7 & 1 & 12 & & & 1 & & 1 \\
\hline
\end{tabular}

*All the isolates are sensitive to teicoplanin and vancomycin. Number of resistant strains is expressed.

Table 7. Corelationship between toxin genes and antibiotic resistance in methicillin-resistant Staphylococcus aureus clinical isolates

\begin{tabular}{|c|c|c|c|c|c|}
\hline Toxin genes/ Antibiotics & Ciprofloxacin & Clindamycin & Erythromycin & Gentamicin & Tetracycline \\
\hline Total $(n=75)$ & 69.3 & 61.3 & 89.3 & 70.7 & 58.7 \\
\hline \multicolumn{6}{|l|}{ Individual type } \\
\hline$s e b(\mathrm{n}=17)$ & 94.1 & 70.6 & 94.1 & 94.1 & 100.0 \\
\hline $\sec (\mathrm{n}=39)$ & 87.2 & 82.9 & 87.2 & 79.5 & 94.9 \\
\hline $\operatorname{seg}(n=39)$ & 82.1 & 82.9 & 86.0 & 67.4 & 81.4 \\
\hline sei $(n=41)$ & 78.0 & 77.1 & 87.8 & 68.3 & 80.5 \\
\hline tst $(\mathrm{n}=35)$ & 85.7 & 62.9 & 94.3 & 74.3 & 91.4 \\
\hline \multicolumn{6}{|l|}{ Coexisting type } \\
\hline seb, sec, seg, sei, tst $(\mathrm{n}=17)$ & 94.1 & 70.6 & 94.1 & 94.1 & 100.0 \\
\hline sec, seg, sei, tst $(\mathrm{n}=14)$ & 92.9 & 71.4 & 92.9 & 71.4 & 92.9 \\
\hline None $(n=23)$ & 65.2 & 52.2 & 95.7 & 78.3 & 13.0 \\
\hline
\end{tabular}

90\% 이상, tst 유전자 보유 균주들은 tetracycline 에 대한 내성 율이 $90 \%$ 이상이었다. 5 개의 독소유전자 $(\mathrm{seb}, \mathrm{sec} s \mathrm{seg} s \mathrm{i}, \mathrm{ts} t)$ 와 4 개의 독소유전자 $(\mathrm{sec}, \mathrm{seg} s \mathrm{sei}, \mathrm{ts} t)$ 를 동시에 보유한 MRSA 균 주들은 ciprofloxacin과 tetracycline에 대한 내성율이 $90 \%$ 이 상이었다.

\section{고 찰}

순천 소재 1 개 병원의 미생물검사실에서 각기 다른 환자들 의 검체로부터 분리된 MRSA 75 개 균주와 MSSA 24개 균주의
독소유전자 분포와 항생제에 대한 내성의 빈도를 분석하였다. 일반적으로 MRSA 균주들이 MSSA 균주들에 비해 장독소 와 독성 쇼크 증상 독소 1 유전자를 높은 비율로 보유하고 있었다. Leukocidin 유전자(pvi)는 MRSA 균주들에서는 검출 되지 않았고 피부과 외래환자의 혈액과 소변에서 분리된 MSSA 3개 균주에서만 검출되었다. 이 독소는 원내 감염보다 는 주로 피부 감염이나 지역감염 환자로부터 분리된 $S$. aureus 에서 발견된다는 보고와 일치한 결과이다[10].

장독소 유전자 중 sea는 검출되지 않았으며 $s e b$ 는 MRSA 17 개 균주 $(22.7 \%)$ 에서 검출되었으며, sec는 39 개 균주 $(52 \%)$ 에 
서 검출되었다. 이와 같은 결과는 한국의 다른 병원에서 분리 한 MRSA의 독소 유전자 보유율과 비교[18] 할 경우 sea보유율 은 낮고, $s e b$ 와 $s e c$ 보유율은 다소 높은 결과이었다. 한편 MRSA 균주의 독성 쇼크 증상 독소 1 유전자 $(t s t)$ 의 보유율 $46.7 \%$ 는 $\mathrm{Kim}$ 등[18]의 결과와 유사한 값이었다.

2개 이상의 독소유전자를 보유한 MRSA 균주는 44 개였다. 다른 보고에서도 대부분의 MRSA균주가 2-4개의 독소유전자 를 동시에 보유하고 있다는 것과 일치한다 $[15,18]$. 특히, $\mathrm{sec}$, $s e g$ sei와 tst 유전자는 31개 균주(41.3\%)가 동시에 보유하고 있었고, seg sei와 tst유전자는 3개 균주가 동시에 보유하였다. $s e c, s e g, s e i$ 와 $t s t$ 유전자의 동시보유율은 79.1-82.9\%로서 4 개의 유전자간의 상관성이 비교적 높게 나타났다(Table 5). 많은 연 구들에서 S. aureus가 tst와 sec유전자를 동시에 보유한다는 것 은 이미 알려져 있었으나[11,17,34], 이번 연구를 통해 $t s t$ 가 $s e c$ 외에도 $s e g$ 와 $s e i$ 유전자와 동시에 검출됨을 확인할 수 있었다 [16]. 이는 유방암에 걸린 소의 원유로부터 분리한 $S$. aureus 에서 나타난 $\mathrm{sec}, \mathrm{seg}, \mathrm{se}$ 와 $t s t$ 유전자간의 동시 보유 $(57.8 \%)$ 현 상과 유사한 결과이다[16]. 검체 제공자의 거주 및 생활 환경에 대한 분석과 병원 소재 인근 지역의 가축으로부터 분리된 $\mathrm{MRSA}$ 의 독소 유전자형의 분석이 이루어질 경우 위의 4 가지 독소 유전자의 동시보유현상의 원인과 경로를 해석할 수 있을 것이라 사료된다.

MRSA의 항생제 내성 비율은 $\beta$ lactam계, quinolone계, amikacin을 제외한 aminoglycoside계, 그리고 tetracycline에 대해 높은 내성율을 나타냈다. 이와 같은 현상은 다른 연구 결과들과 일치한다고 볼 수 있다[2].

특정 독소유전자의 보유가 특정 항생제에 대한 내성과의 연관성을 분석한 결과 MRSA 균주들에서는 tst 유전자를 보유 한 41개 균주 중 38 개 균주 $(92.7 \%)$ 가, sec 유전자를 보유한 39개 균주 중 37 개 균주(94.9\%)와 $s e b$ 유전자를 보유한 17 개 균주 $(100 \%)$ 모두가 tetracycline에 대해 내성을 가지고 있었다. 전 체 MRSA 균주들의 $58.7 \%$ 가 이 항생제에 내성을 보인 것과 비교해 볼 때 $t s t, s e c$ 와 $s e b$ 유전자 보유가 tetracycline에 대한 내성과 밀접한 연관을 지닐 수 있다는 것을 확인하였다.

본 연구 결과 MRSA의 독소 유전자의 분포 양상을 확인할 수 있었으며 특히 $s e c, s e g$, sei 및 tst 유전자간의 동시 발현의 연관을 확인하였고, tetracycline에 대한 내성이 sec과 tst 유전 자와의 연관이 높음을 확인하였다. 따라서 sec과 tst 독소 유전 자들의 수평적 이동 등의 추적이 MRSA 확산 방지에 필요할 것이라고 사료된다.

\section{References}

1. Ahn, J. Y., W. B. Kim, D. W. Lee, K. Lee, S. H. Choi, I. S. Kim, and C. H. Seo. 1999. A study of the med, mecA and femA genes of methicillin-resistant Staphylococci. Korean J. Clin. Pathol. 19, 62-69.
2. Akcam, F. Z., G. B. Tinaz, O. Kaya, A. Tigli, E. Ture, and S. Hosoglu. 2009. Evaluation of methicillin resistance by cefoxitin disk diffusion and PBP2a latex agglutination test in mecA-positive Staphylococcus aureus, and comparison of mecA with femA, femB, fem $X$ positivities. Microbiol. Res. 164, 400-403.

3. Bergdoll, M. S. 1983. Enterotoxins, pp. 559-598, In Easton, C. S. F. and C. Adlam (eds.), Staphylococci and staphylococcal infections. Academic Press, London, United Kingdom.

4. Chambers, H. F. 1997. Methicillin resistance in staphylococci: molecular and biochemical basis and clinical implications. Clin. Microbiol. Rev. 10, 781-791.

5. Chini, V., G. Dimitracopoulos, and I. Spiliopoulou. 2006. Occurrence of the enterotoxin gene cluster and the toxic shock syndrome toxin 1 gene among clinical isolates of methicillin-resistant Staphylococcus aureus is related to clonal type and agr group. J. Clin. Microbiol. 44, 1881-1883.

6. Choe, H. N., C. Park, H. R. Kim, K. S. Baik, S. N. Kim, and C. N. Seong. 2010. Characteristics and antibiotic susceptibility of imipenem-resistant clinical isolates producing carbapenemase. J. Life Sci. 20, 1214-1220.

7. CLSI. 2009. Performance standards for antimicrobial susceptibility testing. 19th Informational Supplement. CLSI document M100-S19 (ISBN 1-56238-690-5). Wayne, PA: Clinical and Laboratory Standards Institute.

8. Diep, B. A., H. A. Carleton, R. F. Chang, G. F. Sensabaugh, and F. Perdreau-Remington. 2006. Roles of 34 virulence genes in the evolution of hospital- and community-associated strains of methicillin-resistant Staphylococcus aureus. J. Infect. Dis. 193, 1495-1503.

9. Georgopapadakou, N. H., S. A. Smith, and D. P. Bonner. 1982. Penicillin-binding proteins in a Staphylococcus aureus strain resistant to specific $\beta$-lactam antibiotics. Antimicrob. Agents Chemother. 22, 172-175.

10. Lina, G., Y. Piémont, F. Godail-Gamot, M. Bes, M. O. Peter, V. Gauduchon, F. Vandenesch, and J. Etienne. 1999. Involvement of Panton-Valentine Leukocidin-producing Staphylococcus aureus in primary skin infections and pneumonia. Clin. Infect. Dis. 29, 1128-1132.

11. Ho, G., W. H. Campbell, M. S. Bergdoll, and E. Carlson. 1989. Production of a toxic shock syndrome toxin variant by Staphylococcus aureus strains associated with sheep, goats, and cows. J. Clin. Microbiol. 27, 1946-1948.

12. Iandolo, J. J. 1989. Genetic analysis of extracellular toxins of Staphylococcus aureus. Annu. Rev. Microbiol. 43, 375-402.

13. Jackson, M. P. and J. J. Iandolo. 1986. Sequence of the exfoliative toxin B gene of Staphylococcus aureus. J. Bacteriol. 167, 726-728.

14. Jevons, M. P. 1961. “Celbenin"-resistant staphylococci. Br. Med J. 1, 124-125.

15. Jung, H. J., J. I. Cho, E. S. Song, J. J. Kim, and K. S. Kim. 2005. PCR detection of virulence genes encoding coagulase and other toxins among clinical methicillin-resistant Staphylococcus aureus. J. Microbiol. Biotechnol. 33, 207-214.

16. Katsuda, K., E. Hata, H. Kobayashi, M. Kohmoto, K. Kawashima, H. Tsunemitsu, and M. Eguchi. 2005. Molecular 
typing of Staphylococcus aureus isolated from bovine mastitic milk on the basis of toxin genes and coagulase gene polymorphisms. Vet. Microbiol. 105, 301-305.

17. Kim, J. S., H. S. Kim, W. Song, H. C. Cho, K. M. Lee, and E. C. Kim. 2007. Molecular epidemiology of methicillin-resistant Staphylococcus aureus isolates with toxic shock syndrome toxin and staphylococcal enterotoxin $\mathrm{C}$ genes. Korean J. Lab. Med 27, 118-123.

18. Kim, J. S, W. Song, H. S. Kim, H. C. Cho, K. M. Lee, M. S. Choi, and E. C. Kim. 2006. Association between the methicillin resistance of clinical isolates of Staphylococcus aureus, their staphylococcal cassette chromosome mec (SCCmec) subtype classification, and their toxin gene profiles. Diagn. Microbiol. Infect. Dis. 56, 289-295.

19. Kim, Y. J., D. S. Jeon, and J. R. Kim. 2001. Molecular epidemiologic analysis of methicillin-resistant Staphylococcus aureus using pulsed-field gel electrophoresis. Korean J. Clin. Pathol. 21, 122-128.

20. Lee, C. Y., J. J. Schmidt, A. D. Johnson-Winegar, L. Spero, and J. J. Iandolo. 1987. Sequence determination and comparison of the exfoliative toxin A and toxin B genes from Staphylococcus aureus. J. Bacteriol. 169, 3904-3909.

21. Lee, H. J., Y. S. Kim, J. S. Kim, Y. H. Cho, K. G. Lee, J. T. Suh, and S. H. Cha. 2001. A study of $\operatorname{mec} A$ and $\operatorname{fem} A$ of methicillin-resistant Staphylococcus aureus (MRSA) strains isolated from clinical specimens. Korean J. Clin. Pathol. 21, 45-48.

22. Lina, G., Y. Piémont, F. Godail-Gamot, M. Bes, M. O. Peter, V. Gauduchon, F. Vandenesch, and J. Etienne. 1999. Involvement of Panton-Valentine leukocidin-producing Staphylococcus aureus in primary skin infections and pneumonia. Clin. Infect. Dis. 29, 1128-1132.

23. Loøseth, A., S. Loncarevic, and K. G. Berdal. 2004. Modified multiplex PCR method for detection of pyrogenic exotoxin genes in staphylococcal isolates. J. Clin. Microbiol. 42, 3869-3872.

24. Marrack, P. and J. Kappler. 1990. The staphylococcal enterotoxins and their relatives. Science 248, 705.

25. Mehrotra, M., G. Wang, and W. M. Johnson. 2000. Multiplex PCR for detection of genes for Staphylococcus aureus enterotoxins, exfoliative toxins, toxic shock syndrome toxin 1 , and methicillin resistance. J. Clin. Microbiol. 38, 1032-1035.

26. Monday, S. R. and G. A. Bohach. 1999. Use of multiplex PCR to detect classical and newly described pyrogenic toxin genes in staphylococcal isolates. J. Clin. Microbiol. 37, 3411-3414.

27. Novick, R. P., P. Schlievert, and A. Ruzin. 2001. Pathogenicity and resistance islands of staphylococci. Microbes Infect. 3, 585-594.

28. Oliveira, D. C. and H. De Lencastre. 2002. Multiplex PCR strategy for rapid identification of structural types and variants of the mec element in methicillin-resistant Staphylococcus aureus. Antimicrob. Agents Chemother. 46, 2155-2161.

29. Omoe, K., M. Ishikawa, Y. Shimoda, D. L. Hu, S. Ueda, and K. Shinagawa. 2002. Detection of seg, seh, and sei genes in Staphylococcus aureus isolates and determination of the enterotoxin productivities of $S$. aureus isolates harboring seg, seh, or sei genes. J. Clin. Microbiol. 40, 857-862.

30. Park, S. H., Y. H. Jang, H. Sung, M. N. Kim, J. S. Kim, and Y. J. Park. 2009. Performance evaluation of BD geneOhm MRSA PCR assay for detection of nasal colonization of methicillin-resistant Staphylococcus aureus at endemic intensive care units. Korean J. Lab. Med 29, 439-447.

31. Peacock, S. J., C. E. Moore, A. Justice, M. Kantzanou, L. Story, K, Mackie, G. O'Neill, and N. P. J. Day. 2002. Virulent combinations of adhesin and toxin genes in natural populations of Staphylococcus aureus. Infect. Immun. 70, 49874996.

32. Smibert, R. M. and N. R. Krieg. 1994. Methods for General and Molecular Bacteriology, pp. 607-654, In Gebhardt, P., R. G. E. Murray, W. A. Wood, and N. R. Krieg (eds.), Washington, DC: American Society for Microbiology.

33. Tsen, H. Y., G. K. Yu, and H. H. Hu. 1997. Comparison of type A enterotoxigenic Staphylococcus aureus strains isolated from geographically far distant locations by pulsed field gel electrophoresis. J. Appl. Microbiol. 82, 485-493.

34. Zschöck, M., K. Riße, and J. Sommerhäuser. 2004. Occurrence and clonal relatedness of sec/tst-gene positive Staphylococcus aureus isolates of quartermilk samples of cows suffering from mastitis. Lett. Appl. Microbiol. 38, 493-498. 
초록 : 임상검체로부터 분리된 methicillin 내성 Staphylococcus aureus의 독소 및 항생제 내성

백근식 ${ }^{1} \cdot$ 기광서 $^{1,2} \cdot$ 최한나 $^{1} \cdot$ 박성찬 $^{1} \cdot$ 고은초 ${ }^{1} \cdot$ 김형락 $^{1,2} \cdot$ 성치남 $^{1} \star$

( ${ }^{1}$ 순천대학교 생물학과, ${ }^{2}$ 성가롤로병원 진단검사의학과)

2009년 7월부터 12월까지 순천 소재 한 병원에 내원한 환자의 검체로부터 methicillin 내성 Staphylococcus aureus (MRSA) 75균주와 methicillin 감수성 S. aureus (MSSA) 24균주를 분리하였다. 분리균의 항생제 감수성 조사는 디스크 확산법을 사용하여 측정하였다. 분리균의 독소 유전자 보유는 multiplex $\mathrm{PCR}$ 을 이용하여 장독소 (enterotoxin; SE), 독성 쇼크 증상 독소 1(toxic shock syndrome toxin-1; TSST-1), 피부박탈성 독소(exfoliative toxin; ET) 및 백혈구 용해 독소(Panton-Valentine leukocidin; PVL) 유전자를 검출하였다. 분리된 MRSA 60개 균 주는 1 개 혹은 2 개의 독소 유전자를 가지고 있으며, $22.7 \%$ 의 균주가 $s e b, s e c, s e g, s e i$ 와 $t s t$ 유전자를 동시에 보유하 고 있었으며 $18.7 \%$ 는 $s e c, s e g$, seif 화 tst 유전자를 동시에 보유하고 있었다. 백혈구 용해독소를 암호하는 $p v l$ 유전자 는 검출되지 않았다. MRSA는 $s e c, s e g, s e i$ 와 tst 유전자 보유에 높은 상관성을 보였다. MRSA 균주들은 erythromycin (분리균의 $89 \%$ ), gentamicin $(70.7 \%)$, ciprofloxacin $(69.3 \%)$, clindamycin $(61.3 \%)$ 과 tetracycline $(58.7 \%)$ 에 내성이 높은 반면, MSSA 균주들은 erythromycin를 제외한 다른 항생제에는 민감하였다. 독소 유전자 seb, sec 와 $t s t$ 는 tetracycline 내성과 높은 상관관계가 있었다. 